Volume-V, Issue-02, July-December, 2010

\title{
Employee Participation in Decision Making in RMG sector of Bangladesh: Correlation with Motivation and Performance
}

\author{
MD. ANOWAR HOSSAIN BHUIYAN ${ }^{1}$
}

\begin{abstract}
Participation in decision making in industry results in satisfaction of employees and an increase in productivity and profit. It empowers the employer to achieve the organizational goal. This study was conducted to assess the present situation, nature and types of workers participation and motivation system in Ready Made Garments (RMG) sector of Bangladesh. The study identifies the causes of poor participation of the employees in decision making and correlate between employee participation, motivation and performance. The study revealed that there is a significant positive correlation between decision making, motivation and performance. The study also identified five major causes of poor participation in decision making, such as, absence of willingness of the management, absence of labor union activities, lack of workforce diversity, illiteracy of the workers and political grouping among the workers.
\end{abstract}

\section{INTRODUCTION}

Participation is the mental and emotional involvement of people in group situations that encourages them to contribute to group goals and share responsibility for them. There are three important ideas regarding participation in decision making-involvement, contribution and responsibility. Firstly, participation means meaningful involvement - rather than mere muscular activity. A second concept in participation is that it motivates people to contribute. They are empowered to release their own resources and creativity to achieve the objectives of the organization. Participation especially improves motivation by helping employees understand their paths towards goals. Finally, participation encourages people to accept responsibility for their group activities. It is social processes by which people become self involved in an organization and want to see it work successfully (Newstrom \& Davis, 2004).

\footnotetext{
${ }^{1}$ Lecturer, Management, National University, Gazipur, Bangladesh.
} 
Participation can have statistically significant effects on performance and motivation (Wagner, 1994). Participate practices may provide power opportunities earlier to minority workers in an increasingly diverse workforce, since such workers need not wait until reaching higher organizational levels. It also helps to satisfy the awakening employee need for meaning and fulfillment at work. Participation typically brings higher output and a better quality of output. It tends to improve motivation because employees feel more accepted and involved in the situation. Turnover and absences may be reduced if the employees feel that they have a better place to work (Newstrom \& Davis, 2004).

Employee motivation is the level of energy, communication and creativity that a company's workers bring to their jobs. One approach to employee motivation has been to view, add-ins to an individual's job as the primary factors in improving performance. Endless mixes of employee benefits such as - health care, life insurance, profit sharing, employee stock ownership plans, child care, company cars and more - have been used by companies in their efforts to maintain happy employees in the belief that happy employees are motivated employees. The best employee motivation efforts will focus on what the employees deem to be important. It may happen that employees within the same department of the same organization with better job design and reward systems will show increased longevity with the company, improved productivity and better morale. Empowerment, creativity and innovation, learning facility, quality of life and various monetary incentives are popular methods of motivation (Encyclopedia, 2008).

Employee participation is a very important component of operating for the future enterprise. Participation is helping management to decide in selecting the courses of action in enterprise. It gives the employee an opportunity to express their viewpoints about action. Participating in goal setting, the employees can play a vital role in achieving business target. Workers can select their work schedules which ensure workforce diversity in organization. If the enterprise selects payment and overtime system according to the employees' opinion, it increases productivity of them. So, employee participation has a positive effect on performance and motivation.

\section{STATEMENT OF THE PROBLEM}

Employee participation has an important influence in decision making for organizational effectiveness. If they have participation in this fact, the employees will feel that they are valued in the enterprise. They also provide necessary suggestions and guidelines to the organization for attaining its goal. As a result, development and necessary changes occur fruitfully in (1) setting goals, (2) making 
decisions, (3) solving problems and (4) designing and implementing organizational changes (Gilbraith et.el. 1993). Employees are committed to the desired goals of the organization if they are engaged in decision making and goal setting by exercising their self-directed and self-control activities. They always seek and accept responsibility to involve them in decision making process through intellectual, emotional and physical effort. Participation helps to resolve the conflict and reduce differences between the employees and the management. If importance is given to the employees in decision making, the cost of control also becomes least. So the involvement of employees in decision making process has been considered important in increasing the productivity of an organization.

Employee participation in workplace decision making is essential to motivate the employees. Broad participation in decision making ensures high performance by motivated employees. This participative process increases capacity of employees in problem solving and commitment to the organization's success. The underlying logic is that by involving workers in those decisions that affect them and by increasing their autonomy and control over their work, employees can be made more motivated and more committed to the organization, more productive and more satisfied with their jobs (Ford and Fottler, 1995). Giving employees' decision making authority increases their control over the tasks for which they are held responsible for. Participation tends to improve motivation because employees feel more accepted and involved in the situation. Their self-esteem, job satisfaction and co-operation with management also may improve. So employee participation in management, an important part of human relations, is deemed to be an important tool to boost up their motivation.

RMG sector is the largest foreign currency earning sector for Bangladesh and it expanding every year. Almost 5 million employees are engaged in this sector and they contribute greatly to our national economy. But there are a lot of problems in this sector. Lack of proper employee participation in decision making and motivation is one of them. For this problem our RMG sector faces a number of difficulties. A good number of research works have been done in different fields of RMG sector. But unfortunately, few studies have been conducted to find out about the correlation among decision making, motivation and performance. For this reason, this study tries to assess the present situation of worker participation and motivation system of RMG sector in Bangladesh. The study also identifies the relationship between worker participation, motivation and performance.

\section{LITERATURE REVIEW}

James, Debra and Laurie (2006) reported that while participation in workplace decision making may have positive effects on employees' attitudes toward their 
work, it may have less impact on employee performance. In addition, the cost of implementing participatory management systems may far exceed the actual return. However, the commentators provide numerous professional examples to suggest that participation in workplace decision making in government setting not only improves employees' attitudes toward work, but also increases their performance. Changes in the nature of organization and task environments, employees' desires to participate in workplace decision making, as well as rapid advances in technology facilitating such exchanges, may make participation an even more important determinant of performance in the future

Mariam Jamila, Bakhtear Uddin and Salma Ahmed (2006) reported that both the unskilled and semi-skilled women workers have an opportunity to be employed in the garments industry in Bangladesh. This paper found that women in the garments sectors of Bangladesh are not discriminated because they are women. Albeit there may be individual incidence of gender-based wage discrimination in the garments sector, most of the worker's wage is determined by their skill, hourswork, experience and age.

Participation tends to improve motivation because employees feel more accepted and involved in the situation. Their self-esteem, job satisfaction and cooperation with management may also improve. The results often are reduced conflict and stress, more commitment to goals, and better acceptance of change. Turnover and absence may be reduced because employees feel that they have a better place to work and that they are being more successful in their jobs. The act of participation in itself establishes better communication as people mutually discuss work problems. Management tends to provide workers with increased information about the organization's fiancés and operations, and this sharing of information allows employees to make better-quality suggestions (Newstrom \& Davis, 2004).

Bashir et. el. (2003) identified that the job design, structure and its relation to the motivation and performance of the employees in insurance industry sector of Bangladesh. A redesigned interview schedule study was conducted on 40 executives of various levels of two insurance companies in the private and public sectors. The finding of the study reveals that executives of the insurance sector in Bangladesh are motivated in their job in terms of task variety, clearly defined authority and responsibility, accountability, information processing, internal co-ordination and job security.

Sen and Khan (2003) showed a brief analysis on participative management visà-vis quality control circles in the context of some banks of Bangladesh. This study has laid emphasis on (a) the philosophy underlying participative management, (b) quality control circles, their essentials and importance, (c) quality audit and (d) 
adverse impact when quality circles fail. This paper may give some ideas about how quality circles and participative management can go together to attain the organizational objectives.

Emran M.A (2001) revealed that the extent of workers' participation in the public sector industries is yet limited. The study puts forward steps necessary for an increase worker participation in management of the public sector industries, particularly in the Khulna Newsprint Mills Ltd.

In the practice of decision making (Kneeland, 1999) and meeting management (Doyle \& Straus, 1976) there is agreement that everyone engaged in a decision process or meeting should understand his or her role. The ladder of decision making helps to define that role. The ladder provides a way to articulate who makes the decision and offers employees more certainty about how their input, which consumes their time and resources, will be used. From these benefits, the ladder offers even greater benefit of improving the quality of decisions by incorporating employee values, information and alternatives to the decision. It also increases the potential for decisions to be implemented as employees help make and "own" the decisions. And the ladder offers the possibility of reducing employee skepticism about executive decisions and executive efforts to engage in employees' numberone issue, time and resources.

Connor P.E. (1992) identified that emphasized by being personally and meaningfully involved, above and beyond just doing assigned tasks, employees are said to be more motivated and productive.

Hossain M N (1992) revealed that job security is a de-motivating factor. But the study of Bashir et al (2003) reported that job security proves as a significant factor for both government and non-government enterprise.

Roethlisberger, Coch and French and others conducted research on this topic. Their collective results suggested the general proposition that participation tends to improve performance and job satisfaction (Coch, 1948). Later research in organizations has repeatedly supported this proposition, as suggested by the authors of a comprehensive review "participation can have statistically significant effects on performance and satisfaction (Wagner, 1994). Participative practices may also provide power opportunities earlier to monitory workers in an increasingly diverse workforce, since such workers need not wait until reaching higher organizational levels before being allowed to contribute meaningfully. Participation also seems to help satisfy the awakening employee need for meaning and fulfillment at work. The use of participative practices is noteworthy. The educational level of the workforce often provides workers with unique capacities that can be applied creatively to work problems. These employees also acquire a greater desire for influencing work- 
related decisions and an expectation that they will be allowed to participate in these decisions (Newstrom \& Davis, 2004).

\section{OBJECTIVES OF THE STUDY}

The purpose of the study is to investigate the workers participation in decision making of the Bangladesh RMG sector. The specific objectives of the study are:

1. To assess the present situation of the workers participation in decision making and motivation system of RMG sector of Bangladesh.

2. To identify the nature and types of participation in decision making and motivation system.

3. To correlate between employee participation in decision making, motivation and performance.

4. To identify the causes of poor participation in decision making.

5. To make suggestions for managerial policy implications in the light of the findings of the present study.

\section{METHODOLOGY}

The sample of the study consisted of 100 workers from five selected garment factories situated in and around Dhaka city and Gazipur district. Data were collected from 20 workers from each factory. A close ended structured questionnaire with 13 items has been used for data collection. The performance related data were obtained from the factory records. Both parametric and non parametric statistical tools were used to analyse the data.

\section{RESULTS}

Results of the study have been summarized in the following Table and analysis:

Table-1 reveals the distribution of employees according to their service experience. The Table shows that $60 \%$ employees are with more than two years' experience. 20\% are of 0-1 year' and 1-2 years' experience. The Table shows the distribution of employees according to their age. In this Table $48 \%$ of the respondents are within 25-30 age range. Again 34\% and 18\% respondents are 20-25 and 30-35 age range respectively. The table reveals the distribution of respondents according to their educational background. 52\% of the respondents are below SSC and $24 \%$ of the respondents are both SSC and HSC level. The Table exhibits the distribution of employees according to their skill level. 54\% of the respondents are

skilled level. Again $32 \%$ and $14 \%$ of the respondents are semiskilled and unskilled level. 
TABLE 1

DISTRIBUTION OF RESPONDENTS ACCORDING TO THEIR SERVICE EXPERIENCE, AGE, EDUCATIONAL BACKGROUND AND SKILL LEVEL

\begin{tabular}{llllc}
\hline \multicolumn{1}{c|}{ Variables } & Range & Frequency & \% of the respondents \\
\hline Experience & 0-1 year & 20 & $20 \%$ \\
& $1-2$ years & 20 & $20 \%$ \\
& $2+$ years & 60 & $60 \%$ \\
Age & $20-25$ & 34 & $34 \%$ \\
& $25-30$ & 48 & $48 \%$ \\
Educational Status & Below SSC & 18 & $18 \%$ \\
& SSC & 52 & $52 \%$ \\
& HSC & 24 & $24 \%$ \\
Skill Level & Unskilled & 24 & $24 \%$ \\
& Semiskilled & 14 & $14 \%$ \\
& Skilled & 32 & $32 \%$ \\
\hline
\end{tabular}

TABLE-2

LEVEL OF DECISION MAKING WITH MANAGEMENT

\begin{tabular}{lcc}
\hline Decision making level & Frequency & $\%$ of the respondents \\
\hline Top level & 70 & $70 \%$ \\
Middle level & 20 & $20 \%$ \\
Lower level & 07 & $07 \%$ \\
Workers level & 03 & $03 \%$ \\
\hline
\end{tabular}

Table-2 shows the distribution of employees according to their opinion in level of managerial decision making. According to the opinion of the respondents $70 \%$ decision making are held at top level. On the other hand $20 \%$ and $7 \%$ decision making occurs in middle and lower level respectively. Again the results show that the workers level participation is only $3 \%$. 
TABLE-3

DIRECT PARTICIPATION IN DECISION MAKING BY THE RMG WORKERS

\begin{tabular}{l|c}
\hline Participation Activities & $\%$ of the respondents \\
\hline Managerial activities & $02 \%$ \\
Goal setting & $0.5 \%$ \\
Other activities & $0.5 \%$ \\
\hline
\end{tabular}

Note: Here show the $3 \%$ workers level participation.

Table-3 exhibits the direct participation in different level of decision making. According to the respondents, $2 \%$ participate in managerial activities. Again $0.5 \%$ workers participate in both goal setting and other activities.

TABLE-4

MOTIVATION ACTIVITIES FOR THE WORKERS OF GARMENT SECTOR

\begin{tabular}{l|c|c}
\hline \multicolumn{1}{c}{ Participation in Activities } & Frequency & \% of the respondents \\
\hline Bonus & 30 & $30 \%$ \\
Transport facility & 25 & $25 \%$ \\
Canteen facility & 20 & $20 \%$ \\
Medical facility & 15 & $15 \%$ \\
Profit sharing & 10 & $10 \%$ \\
\hline
\end{tabular}

Table-4 exhibits the motivational activities for the workers of garments sector. $30 \%$ of the respondents feel that they have participation in bonus system. On the other hand, $25 \%$ and $20 \%$ of the respondents have participation in transport and canteen facility respectively. Again $15 \%$ of the respondents have participated in medical facility. Only $10 \%$ of the respondents feel that they have participation in profit sharing of the garments sector.

TABLE-5

\section{CORRELATION MATRIX SHOWING CORRELATION AMONG SELECTED VARIABLES SUCH AS PARTICIPATION IN DECISION MAKING, MOTIVATION AND PERFORMANCE}

\begin{tabular}{l|l|l}
\hline Variables & 1 & 2 \\
\hline 1. Participation in decision making & 1.00 & \\
2. Motivation & $.24^{*}$ & \\
3. Performance & $.48^{*}$ & $.42^{* *}$ \\
\hline
\end{tabular}

Note: $\mathrm{N}=100$ One-tailed significance; $*=.01, * *=.001$ 
Table-5 reveals that participation of decision making has significant positive correlation with motivation and performance of the RMG employees.

TABLE-6

\section{CAUSES OF POOR PARTICIPATION IN DECISION MAKING AS PERCEIVED} BY THE RESPONDENTS OF THE GARMENT INDUSTRY (N=100)

\begin{tabular}{l|c|c}
\hline \multicolumn{1}{c|}{$\begin{array}{c}\text { Perceived causes of poor participation in } \\
\text { decision making }\end{array}$} & $\begin{array}{c}\text { Percentage of the } \\
\text { respondents who } \\
\text { hold the views }\end{array}$ & Rank order \\
\hline Absence of willingness of the management & 60.50 & 1 \\
Absence of labor union activities & 45.50 & 2 \\
Lack of workforce diversity & 40.00 & 3 \\
Illiteracy of the workers & 30.00 & 4 \\
Political grouping among the workers & 24.00 & 5 \\
\hline
\end{tabular}

Note: Percentages add upto $200 \%$ as each person made two choices.

The result (Table-6) exhibits that the respondents identified 5 (five) important causes of poor participation in decision making. The highest percentages of the respondents feel that absence of willingness of the management is the most important cause. Next in order of importance are the absence of labor union activities, lack of workforce diversity, illiteracy of the workers and political grouping among the workers.

\section{DISCUSSION}

The present study attempts to describe the present situation of worker participation in decision making and motivation in the RMG sector. The result is, as table-2 shows, that the highest decision making occurs at top level of RMG sector and there is only $3 \%$ worker participation in decision making at the lowest level.

Table-3 reveals that in the workers level participation $2 \%$ workers participate directly in managerial activities while $0.5 \%$ participate in goal setting and $0.5 \%$ in other activities.

Table- 4 shows that the motivational activities such as bonus, transport facility, canteen and medical facility are used for the workers of garment sector. But only $10 \%$ of the respondents feel that they participate in profit sharing activities.

Table-5 exhibits that participation in decision making has significant positive correlation among the motivation and performance of the employees. The result is supported by the result of James, Debra and Laurie (2006). 
The results revealed in table- 6 show that the respondents of garments industry have identified 5 causes of poor worker participation in decision making. These are absence of willingness of the management, absence of labor union activities, lack of workforce diversity, illiteracy of the workers and political grouping among the workers.

\section{CONCLUSION AND IMPLICATIONS}

Several major conclusions emerged from the present study:

1. Decision making by the management is mostly done in top level and at worker level it is the lowest, only $3 \%$.

2. Direct participation in decision making has occurred in managerial activities and goal setting in a limited range.

3. Participation in decision making has positive correlation with motivation and performance.

4. Only few motivational activities such as bonus, transport, canteen, medical facility and profit sharing are used in garment sector for motivating the employees.

5. The workers of garments industry identified five major causes of poor participation in decision making, such as absence of willingness of the management, absence of labor union activities, lack of workforce diversity, illiteracy of the workers and political grouping among the workers.

The findings may have significance for government, the policy makers in the RMG industry as well as the management of the manufacturing industry. The findings seem to have wide implications in the present context of garment sector in Bangladesh. Management of a garment industry can benefit immensely by adopting appropriate measures, in the light of the present study by reducing poor participation of the workers in decision making.

\section{REFERENCES}

Bashir et al (2003), A Study of Relationship among Job Design, Motivation and Performance of the Employees in the Insurance Sector of Bangladesh, Insurance journal, Vol.54, Bangladesh Insurance Academy, Dhaka, pp. 35-58.

Connor P.E (1992) "Decision-making Participation Patterns: The role of Organizational Context", Academy of Management Journal, Vol. 35(March), pp.218-231.

Doyle, M. and Strauss, D. (1976) "How to Make Meeting Work". Jove publications.

Emran M A (2001) “The practice of Workers' Participation in Management: A case Study of Khulna Newsprint Mills Ltd.”, Journal of the Institute of Bangladesh Studies, Vol. XXIV, pp. 191-202.

Encyclopedia (2008): http://www.inc.com/encyclopedia/employee-motivation.html 
Ford C.R. and Myron D. F. (1995), "Empowerment: A Matter of Degree", Academy of Management Executive, 9 (August): 21-31.

Gilbrith, J.R., Edward e Lawler III and Associates (1993), "Organization for the Future: The New Logic for Managing Complex Organizations", (San Francisco: Jossey- Bass); Chapter 6\&7.

Hossain M.N (1992), "Job Satisfaction of Secondary School Teachers in Bangladesh: A Case Study in Dhaka City", Journal of Behavioral Science, 3, 2.

James, Debra and Laurie (2006), "Motivating Employees in a New Governance Era: The Performance Paradigm Revisited", The Premier Journal of Public Administration, Vol.66 No.4, http:// www.joe.org.

Kneeland, S. (1999), "Effective Problem Solving: How to Understand the Process and Practice it Successfully", How to Books, Oxford, England.

Lester Coch and John R.P. (1948), "Overcoming Resistance to Change", Human Relations, Vol.1, no. 4, pp. 512-532.

Mariam Jamila, Bakhtear Uddin and Salma Ahmed (2006), "Wage Discrimination in the Garments Sector of Bangladesh", South East University Journal of Business Studies, Vol.2, pp.221-230.

Newstrom J.W. and Davis Keith (2004), Organizational Behavior, Human Behavior at Work (1 $1^{\text {th }}$ Edition), Tata Mcgraw- Hill Co. Ltd. New Delhi, pp.187-200.

Sen and Khan (2003), "Participative Management vis-à-vis Quality Control Circles in Banks: Bangladesh Panorama", Journal of Management Studies, University of Dhaka, Vol. 8\&9, pp. 191-202.

John A. Wagner III (1994) "Participation's Effects on Performance and Satisfaction: A Reconsideration of Research Evidence", Academy of Management Review, Vol.19, no.2, pp.312-330. 